\title{
EVALUASI PASCA PELATIHAN KADER POSBINDU PTM ANGKATAN I DI LATKESMAS MURNAJATI TAHUN 2020 DENGAN PENDEKATAN MODEL KIRKPATRIC
}

\author{
DONY NOERLIANI \\ UPT Latihan Kesehatan Masyarakat Murnajati Jawa Timur \\ Email : donynoerliani@gmail.com
}

\begin{abstract}
ABSTRAK
Penyakit Tidak Menular (PTM) dapat dicegah dengan mengendalikan factor resikonya. Upaya untuk menunjang program pemerintah dalam pengendalian factor resiko PTM serta terlaksananya pencegahan dan pengendalian factor resiko PTM berbasis peran serta masyarakat secara terpadu, rutin dan periodic maka diperlukan strategi khusus yaitu dengan pendidikan dan pelatihan kader Posbindu PTM. Tujuan dari penelitian ini adalah untuk mengevaluasi perubahan perilaku peserta Diklat Kader Posbindu PTM angkatan I dalam menerapkan hasil belajarnya pada pelaksanaan tugas sebagai kader Posbindu PTM di wilayah kerjanya. Penelitian ini merupakan penelitian deskriptif kualitatif untuk mengevaluasi perubahan perilaku peserta Diklat Kader Posbindu PTM I dengan metode evaluasi Kicrpatrick tahap tiga dengan sumber data peserta diklat, kader Posbindu PTM dan PJ PTM di tempat peserta Diklat Kader Posbindu PTM I. Pengambilan data secara daring dengan google drive dan observasi oleh enumerator. Pengambilan data dilakukan sepuluh (10) bulan setelah pelatihan. Hampir seluruh peserta diklat telah menindaklanjuti Rencana Tindak Lanjut yang telah dibuat yaitu pelaporan, sosialisasi, dan penyusunan rencana kerja. Sebagian besar peserta diklat telah melaksanakan upaya pencegahan dan pengendalian Faktor Resiko PTM secara preventif, promotif, deteksi dini dan monitoring serta pelaksanaan rujukan pada warga dengan resiko dan melaksanakan pencatatan dan pelaporan. Posbindu PTM merupakan wujud peran serta masyarakat dalam kegiatan deteksi dini, monitoring dan tindak lanjut dini factor resiko PTM secara mandiri dan berkesinambungan. Pelatihan diperlukan untuk pengembangan diri kader agar penyelenggaraan Posbindu menjadi lebih efekltif oleh karena itu diperlukan evaluasi pelatihan yang telah dilaksanakan untuk mendapatkan informasi tentang efektifitas dan tingkat ketercapaian dari suatu pendidikan dan pelatihan.
\end{abstract}

Kata kunci : Evaluasi Pasca Pelatihan, Kader Posbindu, Model Kirkpatric

\section{PENDAHULUAN}

Saat ini penyakit tidak menular (PTM) menjadi penyebab kematian utama dari seluruh kasus kematian yang terjadi di seluruh dunia. Menurut perkiraan WHO, kematian akibat PTM akan meningkat $15 \%$ secara global antara tahun 2010 sampai tahun 2030, (primiyani, Masruf, \& Hardisman, 2019). Penyakit tidak menular merupakan penyakit yang seringkali tidak terdeteksi karena tidak bergejala dan tidak ada keluhan sehingga datang sudah terlambat atau pada stadium lanjut. Peningkatan prevalensi PTM berdampak terhadap peningkatan beban pembiayaan kesehatan yang harus ditanggung negara dan masyarakat. Penyandang PTM memerlukan biaya yang relative mahal, terlebih bila kondisinya berkembang menjadi kronik dan terjadi komplikasi. Data Pusat Pemeliharaan Jaminan Kesehatan Kementerian Kesehatan RI pada tahun 2012 memperlihatkan bahwa PTM menghabiskan biaya pengobatan yang cukup besar bila dibandingkan dengan biaya pengobatan tertinggi dari seluruh penyakit menular. (Pedoman Umum Pos Pembinaan Terpadu Penyakit Tidak Menular, 2014).

PTM (Penyakit Tidak Menular) dapat dicegah dengan mengendalikan factor resikonya, yaitu merokok, diet yang tidak sehat, kurang aktifitas dan konsumsi minuman beralkohol. Mencegah dan mengendalikan factor resiko relative lebih murah bila dibandingkan dengan biaya pengobatan PTM. Peningkatan kesadaran dan kepedulian masyarakat terhadap factor resiko PTM sangat penting dalam pengendalaian PTM. Salah satu strategi pengendalian PTM yang efisien dan efektif adalah pemberdayaan dan peningkatan peran serta masyarakat. 


\section{COMMUNITY : Jurnal Pengabdian Kepada Masyarakat Vol. 1 No. 1 Mei 2021 e-ISSSN : 2797-0159 | p-ISSN : 2797-0574}

Masyarakat diberikan fasilitas dan bimbingan untuk ikut berpartisipasi dalam pengendalian factor resiko PTM dengan dibekali pengetahuan dan ketrampilan untuk melakukan deteksi dini, monitoring factor resiko PTM serta tindak lanjutnya. Kegiatan ini disebut Pos Pembinaan Terpadu (Posbindu) PTM. Posbindu PTM merupakan salah satu bentuk upaya kesehatan bersumber daya masyarakat (UKBM) dalam pengendalian faktor resiko PTM yang berada di bawah pembinaan Puskesmas. Posbindu PTM dibangun berdasarkan komitmen bersama dari seluruh elemen masyarakat yang peduli terhadap ancaman PTM. (Kurikulum Pelatihan Bagi Tenaga PelatihTraining of Training (TOT) Pengendalian Faktor Risiko Penyakit Tidak Menular Bagi Kader Posbindu Di Wilayah Kerja, 2019)

Untuk menunjang program pemerintah dalam upaya pengendalian FR PTM serta terlaksananya pencegahan dan pengendalian FR PTM berbasis peran serta masyarakat secara terpadu, rutin dan periodic maka diperlukan strategi kegiatan khusus salah satu diantaranya adalah peningkatan kemampuan dan ketrampilan masyarakat dalam pengendalian FR PTM, sebagai upaya peningkatan pengetahuan dan ketrampilan masyarakat tersebut maka dilakukanlah pendidikan dan pelatihan kader Posbindu PTM. Pendidikan dan pelatihan merupakan upaya pengembangan sumber daya manusia yang dapat berpengaruh secara langsung maupun tidak langsung terhadap kinerja suatu organisasi. Untuk mengetahui efektifitas dan tingkat ketercapaian dari suatu pendidikan dan pelatihan maka dilakukan evaluasi. Evaluasi program diklat dimaksudkan untuk mengetahui sumber daya manusia yang dilatih kompeten dalam menerapkan apa yang diperoleh selama diklat atau tidak selain itu juga untuk mengetahui kontribusi bagi peningkatan kinerja tim dan organisasi. Peran evaluasi program pasca diklat sangat menentukan dalam rangka mengetahui sejauhmana keberhasilan program diklat yang telah dilaksanakan. Ada banyak model evaluasi yang dikembangkan oleh para ahli yang dapat dipakai dalam mengevaluasi program pelatihan salah satunya adalah model evaluasi yang dikembangkan oleh dua bersaudara yaitu Kirkpatrick,D.L., \& KirkpatrickJ.D. Kirkpatrick bersaudara menyatakatan bahwa alasan utama dilakukannya kegiatan evaluasi adalah untuk menetukan tingkat efektifitas dari suatu program pelatihan, sehingga ketika kegiatan evaluasi sudah dilakukan diharapkan dapat menjadi dasar bagi pihak-pihak yang bertanggung jawab, dalam membuat keputusan berdasarkan hasil evaluasi. Kirkpatrick bersaudara telah mengembangkan model evalauasi pelatihan yang terkenal dengan Kirkpatrick Four Level Evaluation Model.

Model empat level Kirkpatrick merupakan model evaluasi yang secara luas diterima dan digunakan karena sederhana, lengkap, jelas dan mudah untuk dilakukan. Bates, R.(2004) dalam Ramadhan (2016) menyatakan bahwa model empat level mempunyai kemampuan dalam menyederhanakan proses evaluasi pelatihan yang kompleks, dengan dua cara, yaitu model empat level mempresentasikan pedoman langsung mengenai jenis pertanyaan yang harus ditanyakan dan kriteria yang mungkin sesuai, dan model tersebut mengurangi kebutuhan pengukuran dalam evaluasi pelatihan. Lin dan Chuang (2011) dalam Ritonga,S,(2019) menyatakan model evaluasi empat level Kirkpatrick merupakan model evaluasi yang level evaluasinya mencakup keseluruhan program untuk menilai apa yang kita butuhkan. Karena sederhana, lengkap, jelas dan mudah dilakukan hal inilah yang mendasari peneliti memilih model empat level Kirkpatric dalam melakukan evalausi pasca pelatihan kader Posbindu PTM angkatan I di Latkesmas Murnajati tahun 2020. Pada penelitian ini hanya difokuskan pada level tiga (3) dari model evaluasi Kirkpatrick yaitu mengevaluasi perubahan perilaku alumni peserta pelatihan kader Posbindu PTM angkatan I dikarenakan level satu dan dua telah dilaksanakan selama proses pelatihan. Mengingat pelaksanaan pelatihan kader Posbindu PTM angkatan I baru dilaksanakan sepuluh bulan yang lalu dari waktu penelitian untuk itu evaluasi level empat dari model evaluasi Kirkpatrickpun belum bisa dilaksanakan. Penelitian dilakukan di tujuhbelas (17) Posbindu PTM yang merupakan asal alumni Diklat kader Posbindu PTM angkatan I yang tersebar di tiga kabupaten di Jawa Timur yaitu kabupaten Jombang, kabupaten Kediri dan kabupaten Mojokerto. 


\section{COMMUNITY : Jurnal Pengabdian Kepada Masyarakat Vol. 1 No. 1 Mei 2021 e-ISSSN : 2797-0159 | p-ISSN : 2797-0574}

Hasil study pendahuluan dengan beberapa alumni peserta diklat dari daerah yang berbeda didapatkan data bahwa alumni diklat telah melaporkan hasil pelatihan kepada Puskesmas dan kepala desa masing-masing serta telah melakukan sosialisasi hasil diklat kepada kader dan Tim PKK desa. Beberapa alumni peserta diklat menyatakan bahwa pembentukan Posbindu didesanya masih terkendala dengan pandemic Covid 19 sehingga belum bisa dilakukan. Sebagian alumni peserta diklat juga menyatakan Posbindu PTM belum aktif kembali karena ada pandemic Covid 19. Salah satu alumni menyatakan kelengkapan sarana prasarana Posbindu PTM masih terkendala dana. Dari study pendahuluan tersebut ternyata masih ada kendala yang dihadapi alumni diklat dalam penerapan hasil Diklat untuk itulah perlu dilakukannya evaluasi pasca pelatihan. Mengingat pentingnya evaluasi suatu pendidikan dan pelatihan maka peneliti tertarik melakukan penelitian tentang Evaluasi Pasca Pelatihan Kader Posbindu Penyakit Tidak Menular (PTM) Angkatan I di Latkesmas Murnajati Jawa Timur Tahun 2020 dengan pendekatan model Kirkpatrick tahap tiga yaitu mengevalausi perubahan perilaku alumni peserta pelatihan kader Posbindu PTM angkatan I untuk mengetahui efektifitas pelatihan kader Posbindu PTM yang telah dilaksanakan serta untuk melihat kontribusi nyata para kader terhadap upaya pengendalian dan pencegahan factor resiko PTM di wilayah kerja kader masing-masing.

\section{METODE PENELITIAN}

Rancangan penelitian pada penelitian ini adalah deskriptif kualitatif. Penelitian bertujuan untuk mengetahui gambaran perubahan perilaku peserta pelatihan kader Posbindu PTM angkatan I dalam menerapkan hasil belajarnya pada pelaksanaan tugas sebagai kader Posbindu PTM di wilayah kerjanya, serta untuk mengetahui efektifitas pelatihan kader Posbindu PTM yang telah dilaksanakan dan melihat kontribusi nyata para kader terhadap upaya pengendalian dan pencegahan factor resiko penyakit tidak menular di wilayah kerja kader masing-masing. Penelitian dilakukan pada bulan Desember 2020 dengan lokasi penelitian di Posbindu PTM wilayah kerja dinas kesehatan kabupaten Jombang, Posbindu PTM wilayah kerja dinas kesehatan kabupaten Kediri dan Posbindu PTM wilayah kerja dinas kesehatan kabupaten Mojokerto.

Informan dalam penelitian ini berkaitan dengan subyek penelitian yang bisa memberikan informasi terpercaya mengenai elemen yang ada yaitu alumni peserta pelatihan kader Posbindu PTM angkatan I di Latkesmas Murnajati tahun 2020, PJ PTM, kader Posbindu PTM. Sedangkan sumber data sekunder dalam penelitian ini adalah dokumen laporan pelatihan kader Posbindu PTM angkatan I di Latkesmas Murnajati tahun 2020.

\section{HASIL DAN PEMBAHASAN}

\section{Hasil}

\section{A. Diskripsi Hasil Penelitian}

1. Diskripsi hasil wawancara dengan alumni diklat, kader Posbindu PTM dan PJ PTM tentang manfaat pelatihan kader Posbindu PTM.

Segi kemanfaatan dan efektifitas pelatihan kader Posbindu PTM angkatan I adalah : 1) sangat bermanfaat untuk memperbaiki operasional Posbindu, 2) kader mendapatkan tambahan pengetahuan terkini tentang pengelolaan Posbindu PTM yang sesuai standart, 3) kader menjadi lebih paham tentang tupoksinya, lebih aktif, dan mandiri dalam pengelolaan Posbindu PTM, 4) ketrampilan kader meningkat dalam upaya pengendalian dan pencegahan faktor resiko PTM di masyarakat, 5) sangat membantu dan meringankan tugas programmer PTM di Puskesmas.

2. Diskripsi hasil wawancara dengan alumni diklat dan PJ PTM tentang pelaporan hasil pelatihan kader Posbindu PTM oleh alumni.

Seluruh alumni Diklat telah telah melaporkan hasil pelatihannya kepada penanggung jawab posbindu masing-masing yaitu : bidan desa, ketua PKK desa dan programmer Posbindu PTM di Puskesmas. 


\section{COMMUNITY : Jurnal Pengabdian Kepada Masyarakat Vol. 1 No. 1 Mei 2021 e-ISSSN : 2797-0159 | p-ISSN : 2797-0574}

3. Diskripsi hasil wawancara dengan alumni diklat dan kader Posbindu PTM tentang sosialisasi hasil pelatihan kader Posbindu PTM oleh alumni diklat .

Sebagian besar alumni diklat telah mensosialisasikan hasil Diklat kepada seluruh kader Posbindu PTM, bahkan ada yang telah mensosialisasikan kepada tim PKK desanya serta karang taruna. Sebagian kecil menyatakan belum mensosialisasikan karena masih terkendala pandemic Covid 19. Hal senada disampaikan oleh para kader Posbindu bahwa alumni diklat telah mensosialisasikan hasil pelatihan kepada seluruh rekan kader di Posbindu PTM.

4. Diskripsi hasil wawancara dengan alumni diklat, kader Posbindu PTM dan PJ PTM tentang persiapan dan kelengkapan sarana prasarana Posbindu PTM di tempat alumni diklat.

Hampir setengah alumni diklat menyatakan telah tersedianya sarana prasarana posbindu yang cukup, beberapa menyatakan sarana prasarana belum cukup serta masih proses penganggaran dari dana desa, dan 1 partisipan menyatakan selain bantuan dari desa juga melakukan penggalian dana secara mandiri. Klarifikasi yang dilakukan kepada kader posbindu menyatakan hal yang sama bahwa kendalanya ada pada pendanaan. Hal senada juga disampaikan oleh PJ PTM ada beberapa posbindu yang sarana prasarana masih belum mencukupi.

5. Diskripsi hasil wawancara dengan alumni diklat dan kader Posbindu PTM tentang penyusunan rencana kerja Posbindu di tempat alumni diklat .

Sebagian besar alumni diklat telah membuat rencana kerja posbindu untuk tahun 2021 sedangkan hampir setengah alumni diklat dalam proses penyusunan dan pengajuan rencana kerja posbindu dikarenakan adanya pandemic covid dan sebagian kecil belum melakukan karena posbindu baru berdiri.

6. Diskripsi hasil wawancara dengan alumni diklat,kader Posbindu PTM dan PJ PTM tentang dukungan dalam mengimplementasikan hasil pelatihan kader Posbindu PTM oleh alumni diklat.

Alumni diklat menyatakan bahwa dalam mengimplementasikan hasil diklat sangat didukung oleh kepala desa, tokoh agama dan masyarakat, tim PKK desa serta dinas kesehatan/puskesmas setempat. Dukungan dari kepala desa berupa pendanaan Posbindu, sarana prasarana posbindu, intensif kader, pemberian makanan tambahan dan uang transport kader. Dukungan dari tokoh masyarakat berupa keaktifan tokoh masyarakat untuk selalu hadir saat kegiatan posbindu, sosialisasi posbindu, memberikan fasilitasi tempat untuk kegiatan posbindu. Dukungan dari tim PKK desa yaitu anggota tim PKK selalu hadir membantu kegiatan posbindu, mensosialisasikan kegiatan posbindu kepada ibu ibu PKK. Dukungan dari dinas kesehatan/puskesmas setempat adalah mengadakan kegiatan pelatihan, pembinaan, pendampingan kepada kader, memberikan sarana dan prasaran (posbindu kit).

7. Diskripsi hasil wawancara dengan alumni diklat, kader Posbindu PTM dan PJ PTM tentang hambatan dalam mengimplementasikan hasil pelatihan kader Posbindu PTM oleh alumni diklat .

Hampir setengah alumni diklat menyatakan tidak ada hambatan dalam implementasi hasil diklat namun beberapa menyatakan adanya hambatan dalam implementasi dan penyelenggaraan posbindu PTM yaitu sarana prasarana yang belum standard, adanya pandemic covid-19 menyebabkan warga enggan untuk datang ke Posbindu, serta kurangnya kesadaran masyarakat tentang pentingnya deteksi dini penyakit.

8. Diskripsi hasil pelaksanaan upaya pencegahan dan pengendalian FR PTM secara preventif \& promotif oleh alumni diklat setelah dilakukannya pelatihan dapat dilihat pada table 1

Table 1 Diskripsi pelaksanaan pengendalian FR PTM secara preventif dan promotif di Posbindu PTM oleh alumni diklat

\begin{tabular}{cccc}
\hline No Uraian kegiatan & Selalu & Sering Jarang & $\begin{array}{c}\text { Tidak } \\
\text { perna } \\
\text { h }\end{array}$ \\
& & & \\
\end{tabular}


Vol. 1 No. 1 Mei 2021 e-ISSSN : 2797-0159 | p-ISSN : 2797-0574

\begin{tabular}{|c|c|c|c|c|c|}
\hline 1 & Menerapkan hidup sehat pada diri sendiri dan keluarga & $\begin{array}{c}11 \\
64,7 \%\end{array}$ & $\begin{array}{c}4 \\
23,5 \%\end{array}$ & $\begin{array}{c}2 \\
11,8 \%\end{array}$ & $\begin{array}{c}0 \\
0 \%\end{array}$ \\
\hline 2 & $\begin{array}{l}\text { Melakukan motivasi untuk hidup sehat pada keluarga } \\
\text { dan masyarakat }\end{array}$ & $\begin{array}{c}9 \\
52,9 \%\end{array}$ & $\begin{array}{c}6 \\
35,3 \%\end{array}$ & $\begin{array}{c}2 \\
11,8 \%\end{array}$ & $\begin{array}{c}0 \\
0 \%\end{array}$ \\
\hline 3 & $\begin{array}{l}\text { Melakukan konseling perorangan pada setiap kegiatan } \\
\text { Posbindu PTM }\end{array}$ & $\begin{array}{c}11 \\
64,7 \%\end{array}$ & $\begin{array}{c}3 \\
17,6 \%\end{array}$ & $\begin{array}{c}2 \\
11,8 \%\end{array}$ & $\begin{array}{c}1 \\
5,9 \%\end{array}$ \\
\hline 4 & $\begin{array}{l}\text { Melakukan penyuluhan kesehatan factor resiko PTM } \\
\text { pada setiap kegiatan Posbindu }\end{array}$ & $\begin{array}{c}12 \\
70,6 \%\end{array}$ & $\begin{array}{c}3 \\
17,6 \%\end{array}$ & $\begin{array}{c}1 \\
5,9 \%\end{array}$ & $\begin{array}{c}1 \\
5,9 \%\end{array}$ \\
\hline 5 & $\begin{array}{l}\text { Melakukan penyuluhan dampak rokok dan alcohol } \\
\text { terhadap kesehatan pada kegiatan Posbindu PTM }\end{array}$ & $\begin{array}{c}8 \\
47,1 \%\end{array}$ & $\begin{array}{c}6 \\
35,3 \%\end{array}$ & $\begin{array}{c}2 \\
11,8 \%\end{array}$ & $\begin{array}{c}1 \\
5,9 \%\end{array}$ \\
\hline 6 & $\begin{array}{l}\text { Melakukan penyuluhan gizi seimjbang pada kegiatan } \\
\text { Posbindu PTM }\end{array}$ & $\begin{array}{c}11 \\
64,7 \%\end{array}$ & $\begin{array}{c}3 \\
17,6 \%\end{array}$ & $\begin{array}{c}1 \\
5,9 \%\end{array}$ & $\begin{array}{c}2 \\
11,8 \%\end{array}$ \\
\hline 7 & $\begin{array}{l}\text { Melakukan penyuluhan pentingnya aktifitas fisik pada } \\
\text { kegiatan Posbindu PTM }\end{array}$ & $\begin{array}{c}9 \\
52,9 \%\end{array}$ & $\begin{array}{c}6 \\
35,3 \% \\
\end{array}$ & $\begin{array}{c}0 \\
0 \%\end{array}$ & $\begin{array}{c}2 \\
11,8 \%\end{array}$ \\
\hline 8 & $\begin{array}{l}\text { Melakukan demo makanan sehat saat kegiatan } \\
\text { Posbindu PTM }\end{array}$ & $\begin{array}{c}5 \\
29,4 \% \\
\end{array}$ & $\begin{array}{c}5 \\
29,4 \% \\
\end{array}$ & $\begin{array}{c}2 \\
11,8 \% \\
\end{array}$ & $\begin{array}{c}5 \\
29,4 \% \\
\end{array}$ \\
\hline 9 & $\begin{array}{l}\text { Melakukan kunjungan rumah pada warga untuk } \\
\text { memberikan konseling kesehatan }\end{array}$ & $\begin{array}{c}2 \\
11,8 \%\end{array}$ & $\begin{array}{c}5 \\
29,4 \%\end{array}$ & $\begin{array}{c}5 \\
29,4 \%\end{array}$ & $\begin{array}{c}5 \\
29,4 \%\end{array}$ \\
\hline 10 & $\begin{array}{l}\text { Membuat leaflet tentang upaya pencegahan dan } \\
\text { pengendalian factor resiko PTM }\end{array}$ & $\begin{array}{c}0 \\
0 \% \\
\end{array}$ & $\begin{array}{c}5 \\
29,4 \% \\
\end{array}$ & $\begin{array}{c}6 \\
35,3 \% \\
\end{array}$ & $\begin{array}{c}6 \\
35,3 \% \\
\end{array}$ \\
\hline
\end{tabular}

Table 1 tentang pelaksanaan upaya pencegahan dan pengendalian FR PTM secara preventif dan promotif oleh alumni diklat. Ada beberapa kegiatan dimana sebagian besar partisipan jarang dan tidak pernah melakukan yaitu melakukan demo makanan sehat saat kegiatan posbindu, melakukan kunjungan rumah untuk memberikan konseling kesehatan dan membuat leaflet tentang upaya pencegahan dan pengendalian FR PTM.

9. Diskripsi hasil pelaksanaan upaya pengendalian FR PTM dengan deteksi dini dan monitoring oleh alumni diklat setelah dilakukannya pelatihan dapat dilihat pada table 2

Table 2 Diskripsi pelaksanaan pengendalian FR PTM secara preventif dan promotif di Posbindu PTM oleh alumni diklat

\begin{tabular}{|c|c|c|c|c|c|}
\hline Jo & kegiatan & Sel & Ser & Jar & $\begin{array}{l}\text { lidak } \\
\text { Perna } \\
\text { h }\end{array}$ \\
\hline & 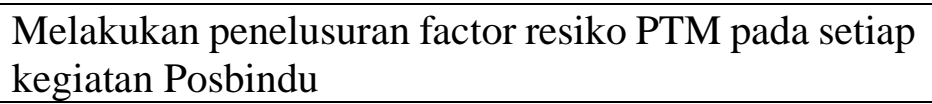 & $\begin{array}{r}6 \\
35,3 \\
\end{array}$ & $\begin{array}{r}8 \\
47,1\end{array}$ & 0 & $\begin{array}{c}3 \\
17,6 \%\end{array}$ \\
\hline & $\begin{array}{l}\text { Melakukan kegiatan pengukuran TB, BB, IMT, } \\
\text { lingkar perut pada setiap kegiatan Posbindu }\end{array}$ & $\begin{array}{c}13 \\
76,5 \% \\
\end{array}$ & $\begin{array}{c}2 \\
11,8 \% \\
\end{array}$ & $\begin{array}{c}0 \\
0 \% \\
\end{array}$ & $\begin{array}{c}2 \\
11,8 \% \\
\end{array}$ \\
\hline & $\begin{array}{l}\text { gukuran tekanan darah pada } \\
\text { PTM }\end{array}$ & $\begin{array}{c}14 \\
82,4 \% \\
\end{array}$ & $\begin{array}{c}1 \\
5,9 \% \\
\end{array}$ & $\begin{array}{c}0 \\
0 \% \\
\end{array}$ & $\begin{array}{c}2 \\
11,8 \% \\
\end{array}$ \\
\hline & $\begin{array}{l}\text { an pemeriksaan gula darah sewaktu pada } \\
\text { giatan Posbindu PTM }\end{array}$ & $\begin{array}{c}9 \\
52,9 \% \\
\end{array}$ & $\begin{array}{c}4 \\
23,5 \% \\
\end{array}$ & $\begin{array}{c}1 \\
5,9 \% \\
\end{array}$ & $\begin{array}{c}3 \\
17,6 \% \\
\end{array}$ \\
\hline 5 & $\begin{array}{l}\text { dkan pemeriksaan kolesterol pada setiap } \\
\text { in Posbindu PTM }\end{array}$ & $\begin{array}{c}7 \\
41,2 \% \\
\end{array}$ & $\begin{array}{c}5 \\
29,4 \% \\
\end{array}$ & $\begin{array}{c}1 \\
5,9 \% \\
\end{array}$ & $\begin{array}{c}4 \\
23,5 \% \\
\end{array}$ \\
\hline b & ayudara/sadanis pada & $\begin{array}{c}1 \\
5,9 \% \\
\end{array}$ & $\begin{array}{c}4 \\
23,5 \% \\
\end{array}$ & $\begin{array}{c}2 \\
11,8 \% \\
\end{array}$ & $\begin{array}{c}9 \\
52,9 \% \\
\end{array}$ \\
\hline 7 & englihatan pada setiap & $\begin{array}{c}6 \\
35,3 \% \\
\end{array}$ & $\begin{array}{c}2 \\
11,8 \% \\
\end{array}$ & $\begin{array}{c}4 \\
23,5 \% \\
\end{array}$ & $\begin{array}{c}4 \\
23,5 \% \\
\end{array}$ \\
\hline 8 & $\begin{array}{l}\text { Melakukan pemeriksaan tajam pendengaran pada } \\
\text { setiap kegiatan Posbindu PTM }\end{array}$ & $\begin{array}{c}4 \\
23,5 \%\end{array}$ & $\begin{array}{c}3 \\
17,6 \% \\
\end{array}$ & $\begin{array}{c}3 \\
17,6 \% \\
\end{array}$ & $\begin{array}{c}6 \\
35,3 \% \\
\end{array}$ \\
\hline . & $\begin{array}{l}\text { Melakukan tindak lanjut dini saat kegiatan Posbindu } \\
\text { PTM }\end{array}$ & $\begin{array}{c}6 \\
35,3 \% \\
\end{array}$ & $\begin{array}{c}5 \\
29,4 \% \\
\end{array}$ & $\begin{array}{c}2 \\
11,8 \%\end{array}$ & $\begin{array}{c}4 \\
23,5 \%\end{array}$ \\
\hline 0 & Melakukan kegiata & 6 & 7 & 2 & 2 \\
\hline
\end{tabular}




\section{$35,3 \% \quad 41,2 \% \quad 11,8 \% \quad 11,8 \%$}

Table 2 tentang pelaksanaan upaya pencegahan dan pengendalian FR PTM dengan deteksi dini dan monitoring oleh alumni diklat. Ada beberapa kegiatan dimana sebagian besar partisipan jarang dan tidak pernah melakukan yaitu pemeriksaan klinik payudara/sadanis ,pemeriksaan tajam penglihatan dan pemeriksaan tajam pendengaran pada setiap kegiatan posbindu PTM, serta tindak lanjut dini saat kegiatan posbindu PTM.

10. Diskripsi hasil pelaksanaan rujukan pada warga dengan FR PTM oleh alumni diklat dapat dilihat pada table 3

Table 3 Diskripsi pelaksanaan rujukan pada warga dengan FR PTM oleh alumni diklat setelah dilakukannya pelatihan

\begin{tabular}{lccccc}
\hline No & Uraian Kegiatan & Selalu & Sering & Jarang & $\begin{array}{c}\text { Tidak } \\
\text { Pernah }\end{array}$ \\
\hline 1 & Melakukan rujukan saat kegiatan Posbindu PTM & 5 & 2 & 4 & 6 \\
& & $29,4 \%$ & $23,5 \%$ & $23,5 \%$ & $35,3 \%$ \\
\hline
\end{tabular}

Table 10 tentang pelaksanaan rujukan pada warga dengan FR PTM oleh alumni diklat 6 dari 17 partisipan tidak pernah melakukan rujukan saat kegiatan Posbindu PTM.

11. Diskripsi hasil pelaksanaan pelaporan FR PTM oleh alumni diklat setelah dilakukan pelatihan dapat dilihat pada table 4

Table 4 Diskripsi pelaksanaan pelaporan FR PTM oleh alumni diklat

\begin{tabular}{llcccc}
\hline No & \multicolumn{1}{c}{ Uraian kegiatan } & Selalu & Sering & Jarang & $\begin{array}{c}\text { Tidak } \\
\text { Pernah }\end{array}$ \\
\hline 1 & $\begin{array}{l}\text { Melakukan pencatatan dan pelaporan Posbindu PTM } \\
\text { secara manual }\end{array}$ & 13 & 3 & 0 & 1 \\
& $\begin{array}{l}\text { Melakukan pencatatan dan pelaporan Posbindu PTM } \\
\text { menggunakan SIM dan Puskesmas }\end{array}$ & 9 & 2 & 0 & 6 \\
& $52,9 \%$ & $11,8 \%$ & $0 \%$ & $35,3 \%$ \\
\hline
\end{tabular}

Table 4 tentang pelaksanaan pelaporan FR PTM oleh alumni diklat yaitu hampir semua partisipan telah melakukan pencatatan dan pelaporan secara manual dan hampir setengah tidak melakukan pencatatan dan pelaporan dengan system informasi manajemen.

12. Diskripsi hasil pengamatan kader Posbindu PTM tentang pelaksanaan upaya pencegahan dan pengendalian FR PTM secara preventif dan promotif oleh alumni diklat dapat dilihat pada table 5.

Table 5 Diskripsi pengamatan kader Posbindu PTM tentang pelaksanaan upaya pencegahan pengendalian FR PTM secara preventif dan promotif oleh alumni diklat

\begin{tabular}{|c|c|c|c|c|c|}
\hline No & Pernyataan & Selalu & Sering & Jarang & $\begin{array}{l}\text { Tidak } \\
\text { pernah }\end{array}$ \\
\hline 1 & $\begin{array}{l}\text { Menerapkan hidup sehat pada diri sendiri dan } \\
\text { keluarga }\end{array}$ & $\begin{array}{c}12 \\
70,6 \% \\
\end{array}$ & $\begin{array}{c}4 \\
23,5 \% \\
\end{array}$ & $\begin{array}{c}1 \\
5,9 \% \\
\end{array}$ & $\begin{array}{c}0 \\
0 \% \\
\end{array}$ \\
\hline 2 & $\begin{array}{l}\text { Melakukan motivasi untuk hidup sehat pada } \\
\text { keluarga dan masyarakat }\end{array}$ & $\begin{array}{c}11 \\
64,7 \%\end{array}$ & $\begin{array}{c}5 \\
29,4 \% \\
\end{array}$ & $\begin{array}{c}1 \\
5,9 \%\end{array}$ & $\begin{array}{c}0 \\
0 \%\end{array}$ \\
\hline 3 & $\begin{array}{l}\text { Melakukan konseling perorangan pada setiap } \\
\text { kegiatan Posbindu PTM }\end{array}$ & $\begin{array}{c}10 \\
58,9 \%\end{array}$ & $\begin{array}{c}4 \\
23,5 \% \\
\end{array}$ & $\begin{array}{c}2 \\
11,8 \%\end{array}$ & $\begin{array}{c}1 \\
5,9 \%\end{array}$ \\
\hline 4 & $\begin{array}{l}\text { Melakukan penyuluhan kesehatan factor resiko } \\
\text { PTM pada setiap kegiatan Posbindu }\end{array}$ & $\begin{array}{c}12 \\
70,6 \%\end{array}$ & $\begin{array}{c}4 \\
23,5 \% \\
\end{array}$ & $\begin{array}{c}1 \\
5,9 \%\end{array}$ & $\begin{array}{c}0 \\
0 \%\end{array}$ \\
\hline 5 & $\begin{array}{l}\text { Melakukan penyuluhan dampak rokok dan } \\
\text { alcohol terhadap kesehatan pada kegiatan } \\
\text { Posbindu PTM }\end{array}$ & $\begin{array}{c}10 \\
58,8 \%\end{array}$ & $\begin{array}{c}5 \\
29,4 \%\end{array}$ & $\begin{array}{c}2 \\
11,8 \%\end{array}$ & $\begin{array}{c}0 \\
0 \%\end{array}$ \\
\hline 6 & $\begin{array}{l}\text { Melakukan penyuluhan gizi seimjbang pada } \\
\text { kegiatan Posbindu PTM }\end{array}$ & $\begin{array}{c}11 \\
64,7 \%\end{array}$ & $\begin{array}{c}4 \\
23,5 \% \\
\end{array}$ & $\begin{array}{c}2 \\
11,8 \% \\
\end{array}$ & $\begin{array}{c}0 \\
0 \%\end{array}$ \\
\hline 7 & $\begin{array}{l}\text { Melakukan penyuluhan pentingnya aktifitas fisik } \\
\text { pada kegiatan Posbindu PTM }\end{array}$ & $\begin{array}{c}11 \\
64,7 \%\end{array}$ & $\begin{array}{c}3 \\
17,6 \% \\
\end{array}$ & $\begin{array}{c}3 \\
17,6 \% \\
\end{array}$ & $\begin{array}{c}0 \\
0 \%\end{array}$ \\
\hline 8 & $\begin{array}{l}\text { Melakukan demo makanan sehat saat kegiatan } \\
\text { Posbindu PTM }\end{array}$ & $\begin{array}{c}6 \\
35,3 \% \\
\end{array}$ & $\begin{array}{c}6 \\
35,3 \% \\
\end{array}$ & $\begin{array}{c}0 \\
0 \% \\
\end{array}$ & $\begin{array}{c}5 \\
29,4 \% \\
\end{array}$ \\
\hline
\end{tabular}




\begin{tabular}{llcccc}
\hline 9 & Melakukan kunjungan rumah pada warga untuk & 5 & 8 & 0 & 4 \\
& memberikan konseling kesehatan & $29,4 \%$ & $47,1 \%$ & $0 \%$ & $23,5 \%$ \\
\hline 10 & $\begin{array}{l}\text { Membuat leaflet tentang upaya pencegahan dan } \\
\text { pengendalian factor resiko PTM untuk disebarkan } \\
\text { ke anggota Posbindu/masyarakat }\end{array}$ & $65,3 \%$ & 6 & 1 & 4 \\
& & $35,3 \%$ & $5,9 \%$ & $23,5 \%$ \\
\hline
\end{tabular}

Table 5 hasil pengamatan kader Posbindu PTM terhadap pelaksanaan upaya pencegahan dan pengendalian FR PTM secara preventif dan promotif oleh alumni diklat. Ada beberapa kegiatan dimana sebagian besar partisipan jarang dan tidak pernah melakukan yaitu demo makanan sehat, kunjungan rumah pada warga untuk memberikan konseling kesehatan, dan membuat leaflet tentang upaya pencegahan dan pengendalian FR PTM untuk disebarkan ke anggota posbindu/masyarakat.

13. Diskripsi hasil pengamatan kader Posbindu PTM tentang pelaksanaan upaya pengendalian

FR PTM dengan deteksi dini dan monitoring dapat dilihat pada table 6.

Table 6 Diskripsi hasil pengamatan kader Posbindu PTM tentang pelaksanaan pengendalian FR PTM dengan deteksi dini dan monitoring di Posbindu PTM oleh alumni diklat

\begin{tabular}{|c|c|c|c|c|c|}
\hline No & Uraian kegiatan & Selalu & Ser & Jar & $\begin{array}{l}\text { Tidak } \\
\text { Pernah }\end{array}$ \\
\hline 1 & $\begin{array}{l}\text { Melakukan penelusuran factor resiko PTM pada } \\
\text { setiap kegiatan Posbindu }\end{array}$ & $\begin{array}{c}11 \\
64,7 \% \\
\end{array}$ & $\begin{array}{c}5 \\
29,4 \% \\
\end{array}$ & $\begin{array}{c}1 \\
5,9 \% \\
\end{array}$ & $\begin{array}{c}0 \\
0 \%\end{array}$ \\
\hline 2 & $\begin{array}{l}\text { Melakukan kegiatan pengukuran TB, BB, IMT, } \\
\text { lingkar perut pada setiap kegiatan Posbindu }\end{array}$ & $\begin{array}{c}14 \\
82,4 \% \\
\end{array}$ & $\begin{array}{c}2 \\
11,8 \%\end{array}$ & $\begin{array}{c}1 \\
5,9 \%\end{array}$ & $\begin{array}{c}0 \\
0 \%\end{array}$ \\
\hline 3 & $\begin{array}{l}\text { Melakukan kegiatan pengukuran tekanan darah pada } \\
\text { setiap kegiatan Posbindu PTM }\end{array}$ & $\begin{array}{c}14 \\
82,4 \% \\
\end{array}$ & $\begin{array}{c}2 \\
11,8 \% \\
\end{array}$ & $\begin{array}{c}1 \\
5,9 \% \\
\end{array}$ & $0 \%$ \\
\hline 4 & $\begin{array}{l}\text { Melakukan pemeriksaan gula darah sewaktu pada } \\
\text { setiap kegiatan Posbindu PTM }\end{array}$ & $\begin{array}{c}10 \\
58,8 \%\end{array}$ & $\begin{array}{c}5 \\
29,4 \% \\
\end{array}$ & $\begin{array}{c}2 \\
11,8 \% \\
\end{array}$ & $\begin{array}{c}0 \\
0 \%\end{array}$ \\
\hline 5 & $\begin{array}{l}\text { Melakukan pemeriksaan kolesterol pada setiap } \\
\text { kegiatan Posbindu PTM }\end{array}$ & $\begin{array}{c}11 \\
64,7 \%\end{array}$ & $\begin{array}{c}2 \\
11,8 \%\end{array}$ & $\begin{array}{c}4 \\
23,5 \%\end{array}$ & $\begin{array}{c}0 \\
0 \%\end{array}$ \\
\hline 6 & $\begin{array}{l}\text { Melakukan pemeriksaan klinik payudara/sadanis } \\
\text { pada setiap kegiatan Posbindu PTM }\end{array}$ & $\begin{array}{c}4 \\
23,5 \%\end{array}$ & $\begin{array}{c}6 \\
35,3 \%\end{array}$ & $\begin{array}{c}2 \\
11,8 \%\end{array}$ & $\begin{array}{c}5 \\
29,4 \%\end{array}$ \\
\hline 7 & $\begin{array}{l}\text { Melakukan pemeriksaan tajam penglihatan pada } \\
\text { setiap kegiatan Posbindu PTM }\end{array}$ & $\begin{array}{c}5 \\
29,4 \% \\
\end{array}$ & $\begin{array}{c}10 \\
58,8 \%\end{array}$ & $\begin{array}{c}1 \\
5,9 \%\end{array}$ & $\begin{array}{c}1 \\
5,9 \%\end{array}$ \\
\hline 8 & $\begin{array}{l}\text { Melakukan pemeriksaan tajam pendengaran pada } \\
\text { setiap kegiatan Posbindu PTM }\end{array}$ & $\begin{array}{c}6 \\
35,3 \% \\
\end{array}$ & $\begin{array}{c}8 \\
47,1 \% \\
\end{array}$ & $\begin{array}{c}2 \\
11,8 \%\end{array}$ & $\begin{array}{c}1 \\
5,9 \%\end{array}$ \\
\hline 9 & $\begin{array}{l}\text { Melakukan tindak lanjut dini saat kegiatan Posbindu } \\
\text { PTM }\end{array}$ & $\begin{array}{c}5 \\
29,4 \% \\
\end{array}$ & $\begin{array}{c}8 \\
47,1 \% \\
\end{array}$ & $\begin{array}{c}2 \\
11,8 \% \\
\end{array}$ & $\begin{array}{c}2 \\
11,8 \% \\
\end{array}$ \\
\hline 10 & Melakuk: & $\begin{array}{c}6 \\
35,3 \% \\
\end{array}$ & $\begin{array}{c}8 \\
47,1 \% \\
\end{array}$ & $\begin{array}{c}1 \\
5,9 \%\end{array}$ & $\begin{array}{c}2 \\
11,8 \%\end{array}$ \\
\hline
\end{tabular}

Table 6 hasil pengamatan kader Posbindu PTM terhadap pelaksanaan upaya pencegahan dan pengendalian FR PTM dengan deteksi dini dan monitoring oleh alumni diklat. Ada beberapa kegiatan dimana sebagian besar partisipan jarang dan tidak pernah melakukan yaitu pemeriksaan klinik payudara/sadanis \& pemeriksaan tajam pendengaran pada setiap kegiatan Posbindu PTM, serta tindak lanjut dini saat kegiatan Posbindu PTM.

14. Diskripsi hasil pengamatan kader Posbindu PTM tentang pelaksanaan rujukan pada warga dengan FR PTM oleh alumni diklat dapat dilihat pada table 7

Table 7 Diskripsi hasil pengamatan kader Posbindu PTM tentang pelaksanaan rujukan pada warga dengan FR PTM oleh alumni diklat

\begin{tabular}{lccccc}
\hline No & Pernyataan & Selalu & Sering & Jarang & $\begin{array}{c}\text { Tidak } \\
\text { Pernah }\end{array}$ \\
\hline 1 & Melakukan rujukan saat kegiatan Posbindu PTM & 5 & 7 & 2 & 3 \\
& & $29,4 \%$ & $41,2 \%$ & $11,8 \%$ & $17,8 \%$ \\
\hline
\end{tabular}


Table 7 hasil pengamatan kader Posbindu PTM terhadap pelaksanaan rujukan pada warga dengan FR PTM oleh partisipan yaitu hampir setengah partisipan pernah melakukan rujukan pada warga dengan FR PTM dan sebagian kecil jarang melakukan rujukan.

15. Diskripsi hasil pengamatan kader Posbindu PTM tentang pelaksanaan pelaporan FR PTM oleh alumni diklat dapat dilihat pada table 8 .

Table 8 Diskripsi pengamatan kaderPosbindu PTM tentang pelaksanaan pelaporan FR PTM

\begin{tabular}{|c|c|c|c|c|c|}
\hline No & Uraian kegiatan & Selalu & Sering & Jarang & $\begin{array}{l}\text { Tidak } \\
\text { Pernah }\end{array}$ \\
\hline 1 & $\begin{array}{l}\text { Melakukan pencatatan dan pelaporan Posbindu PTM } \\
\text { secara manual }\end{array}$ & $\begin{array}{c}12 \\
70,6 \%\end{array}$ & $\begin{array}{c}5 \\
29,4 \% \\
\end{array}$ & $\begin{array}{c}0 \\
0 \%\end{array}$ & $\begin{array}{c}0 \\
0 \%\end{array}$ \\
\hline 2 & $\begin{array}{l}\text { Melakukan pencatatan dan pelaporan Posbindu PTM } \\
\text { dengan SIM dan Puskesmas }\end{array}$ & $\begin{array}{c}9 \\
52,9 \% \\
\end{array}$ & $\begin{array}{c}6 \\
35,3 \% \\
\end{array}$ & $\begin{array}{c}2 \\
11,8 \%\end{array}$ & $\begin{array}{c}0 \\
0 \%\end{array}$ \\
\hline
\end{tabular}

Table 8 hasil pengamatan kader Posbindu PTM terhadap pelaksanaan pelaporan FR PTM oleh partisipan yaitu semua partisipan melakukan kegiatan pencatatan dan pelaporan secara manual maupun dan on line.

16. Diskripsi hasil pengamatan PJ PTM tentang pelaksanaan upaya pencegahan dan pengendalian FR PTM secara preventif \& promotif oleh alumni diklat dapat dilihat pada table 9

Table 9 Diskripsi pengamatan PJ PTM tentang pelaksanaan upaya pencegahan pengendalian FR PTM secara preventif dan promotif oleh alumni diklat

\begin{tabular}{|c|c|c|c|c|c|}
\hline No & ataan & Selalu & Sering & Jarang & $\begin{array}{l}\text { Tidak } \\
\text { pernah }\end{array}$ \\
\hline 1 & $\begin{array}{l}\text { Menerapkan hidup sehat pada diri sendiri dan } \\
\text { keluarga }\end{array}$ & $\begin{array}{c}7 \\
70 \% \\
\end{array}$ & $\begin{array}{c}3 \\
30 \% \\
\end{array}$ & $\begin{array}{c}0 \\
0 \%\end{array}$ & $\begin{array}{c}0 \\
0 \%\end{array}$ \\
\hline 2 & $\begin{array}{l}\text { Melakukan motivasi untuk hidup sehat pada } \\
\text { keluarga dan masyarakat }\end{array}$ & $\begin{array}{c}5 \\
50 \% \\
\end{array}$ & $\begin{array}{c}5 \\
50 \% \\
\end{array}$ & $\begin{array}{c}0 \\
0 \%\end{array}$ & $\begin{array}{c}0 \\
0 \%\end{array}$ \\
\hline 3 & $\begin{array}{l}\text { Melakukan konseling perorangan pada setiap } \\
\text { kegiatan Posbindu PTM }\end{array}$ & $\begin{array}{c}6 \\
60 \% \\
\end{array}$ & $\begin{array}{c}3 \\
30 \% \\
\end{array}$ & $\begin{array}{c}1 \\
10 \% \\
\end{array}$ & $\begin{array}{c}0 \\
0 \% \\
\end{array}$ \\
\hline 4 & $\begin{array}{l}\text { Melakukan penyuluhan kesehatan factor resiko } \\
\text { PTM pada setiap kegiatan Posbindu }\end{array}$ & $\begin{array}{c}3 \\
30 \% \\
\end{array}$ & $\begin{array}{c}6 \\
60 \% \\
\end{array}$ & $\begin{array}{c}1 \\
10 \% \\
\end{array}$ & $\begin{array}{c}0 \\
0 \% \\
\end{array}$ \\
\hline 5 & $\begin{array}{l}\text { Melakukan penyuluhan dampak rokok dan } \\
\text { alcohol terhadap kesehatan pada kegiatan } \\
\text { Posbindu PTM }\end{array}$ & $\begin{array}{c}4 \\
40 \%\end{array}$ & $\begin{array}{c}5 \\
50 \%\end{array}$ & $\begin{array}{c}1 \\
10 \%\end{array}$ & $\begin{array}{c}0 \\
0 \%\end{array}$ \\
\hline 6 & $\begin{array}{l}\text { Melakukan penyuluhan gizi seimjbang pada } \\
\text { kegiatan Posbindu PTM }\end{array}$ & $\begin{array}{c}4 \\
40 \%\end{array}$ & $\begin{array}{c}4 \\
40 \% \\
\end{array}$ & $\begin{array}{c}2 \\
20 \%\end{array}$ & $\begin{array}{c}0 \\
0 \%\end{array}$ \\
\hline 7 & $\begin{array}{l}\text { Melakukan penyuluhan pentingnya aktifitas fisik } \\
\text { pada kegiatan Posbindu PTM }\end{array}$ & $\begin{array}{c}3 \\
30 \% \\
\end{array}$ & $\begin{array}{c}3 \\
30 \% \\
\end{array}$ & $\begin{array}{c}4 \\
40 \% \\
\end{array}$ & $\begin{array}{c}0 \\
0 \%\end{array}$ \\
\hline 8 & $\begin{array}{l}\text { Melakukan demo makanan sehat saat kegiatan } \\
\text { Posbindu PTM }\end{array}$ & $\begin{array}{c}2 \\
20 \%\end{array}$ & $\begin{array}{c}3 \\
30 \% \\
\end{array}$ & $\begin{array}{c}4 \\
40 \%\end{array}$ & $\begin{array}{c}1 \\
10 \%\end{array}$ \\
\hline 9 & $\begin{array}{l}\text { Melakukan kunjungan rumah pada warga untuk } \\
\text { memberikan konseling kesehatan }\end{array}$ & $\begin{array}{c}2 \\
20 \% \\
\end{array}$ & $\begin{array}{c}3 \\
30 \% \\
\end{array}$ & $\begin{array}{c}3 \\
30 \% \\
\end{array}$ & $\begin{array}{c}2 \\
20 \% \\
\end{array}$ \\
\hline 10 & $\begin{array}{l}\text { Membuat leaflet tentang upaya pencegahan dan } \\
\text { pengendalian factor resiko PTM }\end{array}$ & $\begin{array}{c}1 \\
10 \%\end{array}$ & $\begin{array}{c}3 \\
30 \%\end{array}$ & $\begin{array}{c}2 \\
20 \%\end{array}$ & $\begin{array}{c}4 \\
40 \%\end{array}$ \\
\hline
\end{tabular}

Table 9 hasil pengamatan PJ PTM terhadap alumni diklat yaitu ada beberapa kegiatan dimana sebagian besar jarang dan tidak pernah melakukan yaitu demo makanan sehat saat kegiatan Posbindu PTM, penyuluhan tentang pentingnya aktifitas fisik, kunjungan rumah pada warga untuk konseling kesehatan, membuat leaflet tentang upaya pencegahan dan pengendalian FR PTM untuk disebarkan ke anggota Posbindu/masyarakat.

17. Diskripsi hasil pengamatan PJ PTM tentang pelaksanaan upaya pengendalian FR PTM dengan deteksi dini dan monitoring oleh alumni diklat dapat dilihat pada table 10 .

Table 10 Diskripsi hasil pengamatan PJ PTM tentang pelaksanaan pengendalian FR PTM dengan deteksi dini dan monitoring di Posbindu PTM oleh alumni diklat 


\begin{tabular}{|c|c|c|c|c|c|}
\hline No & Uraian kegiatan & Selalu & Sering & Jarang & $\begin{array}{l}\text { Tidak } \\
\text { Pernah }\end{array}$ \\
\hline 1 & $\begin{array}{l}\text { Melakukan penelusuran factor resiko PTM pada } \\
\text { setiap kegiatan Posbindu }\end{array}$ & $\begin{array}{c}3 \\
30 \% \\
\end{array}$ & $\begin{array}{c}5 \\
50 \% \\
\end{array}$ & $\begin{array}{c}2 \\
20 \% \\
\end{array}$ & $\begin{array}{c}0 \\
0 \%\end{array}$ \\
\hline 2 & $\begin{array}{l}\text { Melakukan kegiatan pengukuran } \mathrm{TB}, \mathrm{BB} \text {, IMT, } \\
\text { lingkar perut pada setiap kegiatan Posbindu }\end{array}$ & $\begin{array}{c}4 \\
40 \%\end{array}$ & $\begin{array}{c}6 \\
60 \%\end{array}$ & $\begin{array}{c}0 \\
0 \%\end{array}$ & $\begin{array}{c}0 \\
0 \%\end{array}$ \\
\hline 3 & $\begin{array}{l}\text { Melakukan kegiatan pengukuran tekanan darah } \\
\text { pada setiap kegiatan Posbindu PTM }\end{array}$ & $\begin{array}{c}6 \\
60 \% \\
\end{array}$ & $\begin{array}{c}4 \\
40 \% \\
\end{array}$ & $\begin{array}{c}0 \\
0 \%\end{array}$ & $\begin{array}{c}0 \\
0 \%\end{array}$ \\
\hline 4 & $\begin{array}{l}\text { Melakukan pemeriksaan gula darah sewaktu pada } \\
\text { setiap kegiatan Posbindu PTM }\end{array}$ & $\begin{array}{c}4 \\
40 \% \\
\end{array}$ & $\begin{array}{c}2 \\
20 \% \\
\end{array}$ & $\begin{array}{c}3 \\
30 \% \\
\end{array}$ & $\begin{array}{c}1 \\
10 \%\end{array}$ \\
\hline 5 & $\begin{array}{l}\text { Melakukan pemeriksaan kolesterol pada setiap } \\
\text { kegiatan Posbindu PTM }\end{array}$ & $\begin{array}{c}2 \\
20 \%\end{array}$ & $\begin{array}{c}2 \\
20 \%\end{array}$ & $\begin{array}{c}5 \\
50 \%\end{array}$ & $\begin{array}{c}1 \\
10 \%\end{array}$ \\
\hline 6 & $\begin{array}{l}\text { Melakukan pemeriksaan klinik payudara/sadanis } \\
\text { pada setiap kegiatan Posbindu PTM }\end{array}$ & $\begin{array}{c}3 \\
30 \% \\
\end{array}$ & $\begin{array}{c}2 \\
20 \% \\
\end{array}$ & $\begin{array}{c}3 \\
30 \% \\
\end{array}$ & $\begin{array}{c}2 \\
20 \% \\
\end{array}$ \\
\hline 7 & $\begin{array}{l}\text { Melakukan pemeriksaan tajam penglihatan pada } \\
\text { setiap kegiatan Posbindu PTM }\end{array}$ & $\begin{array}{c}1 \\
10 \% \\
\end{array}$ & $\begin{array}{c}5 \\
50 \% \\
\end{array}$ & $\begin{array}{c}4 \\
40 \% \\
\end{array}$ & $\begin{array}{c}0 \\
0 \%\end{array}$ \\
\hline 8 & $\begin{array}{l}\text { Melakukan pemeriksaan tajam pendengaran pada } \\
\text { setiap kegiatan Posbindu PTM }\end{array}$ & $\begin{array}{c}1 \\
10 \% \\
\end{array}$ & $\begin{array}{c}4 \\
40 \% \\
\end{array}$ & $\begin{array}{c}4 \\
40 \% \\
\end{array}$ & $\begin{array}{c}1 \\
10 \% \\
\end{array}$ \\
\hline 9 & $\begin{array}{l}\text { Melakukan tindak lanjut dini saat kegiatan } \\
\text { Posbindu PTM }\end{array}$ & $\begin{array}{c}2 \\
20 \% \\
\end{array}$ & $\begin{array}{c}6 \\
60 \% \\
\end{array}$ & $\begin{array}{c}1 \\
10 \% \\
\end{array}$ & $\begin{array}{c}1 \\
10 \% \\
\end{array}$ \\
\hline 10 & Melakukan kegiatan senam bersama masyarakat & $\begin{array}{c}1 \\
10 \% \\
\end{array}$ & $\begin{array}{c}6 \\
60 \% \\
\end{array}$ & $\begin{array}{c}2 \\
20 \% \\
\end{array}$ & $\begin{array}{c}1 \\
10 \% \\
\end{array}$ \\
\hline
\end{tabular}

Table 10 hasil pengamatan PJ PTM terhadap alumni diklat yaitu sebagian besar jarang dan tidak pernah melakukan kegiatan yaitu pemeriksaan kolestero pada setiap kegiatan Posbindu PTM, pemeriksaan klinik payudara/sadanis pada setiap kegiatan Posbindu PTM, pemeriksaan tajam penglihatan pada setiap kegiatan Posbindu PTM, pemeriksaan tajam pendengaran pada setiap kegiatan Posbindu PTM.

18. Diskripsi hasil pengamatan PJ PTM tentang pelaksanaan rujukan pada warga dengan FR

PTM oleh alumni diklat dapat dilihat pada table 11

Table 11 Diskripsi pengamatan PJ PTM tentang pelaksanaan rujukan pada warga dengan FR PTM oleh alumni diklat

\begin{tabular}{cccccc}
\hline No & Uraian Kegiatan & Selalu & Sering & Jarang & $\begin{array}{c}\text { Tidak } \\
\text { Pernah }\end{array}$ \\
\hline 1 & Melakukan rujukan saat kegiatan Posbindu PTM & 3 & 3 & 4 & 0 \\
& & $30 \%$ & $30 \%$ & $40 \%$ & $0 \%$ \\
\hline
\end{tabular}

Table 11 hasil pengamatan PJ PTM terhadap alumni diklat yaitu hampir setengah partisipan jarang melakukan rujukan dan hampir setengahnya selalu dan sering melakukan rujukan pada warga dengan resiko PTM.

19. Diskripsi hasil pengamatan PJ PTM tentang pelaksanaan pelaporan FR PTM oleh alumni diklat dapat dilihat pada table 12 .

Table 12 Diskripsi pengamatan PJ PTM tentang pelaksanaan pelaporan factor resiko PTM

\begin{tabular}{llcccc}
\hline No & \multicolumn{1}{c}{ Uraian kegiatan } & Selalu & Sering & Jarang & $\begin{array}{c}\text { Tidak } \\
\text { Perna } \\
\text { h }\end{array}$ \\
\hline 1 & & & & 0 \\
& $\begin{array}{l}\text { Melakukan pencatatan dan pelaporan Posbindu PTM } \\
\text { secara manual }\end{array}$ & 5 & 4 & 1 & 0 \\
\hline 2 & $\begin{array}{l}\text { Melakukan pencatatan dan pelaporan Posbindu PTM } \\
\text { dengan menggunakan SIM }\end{array}$ & 1 & 2 & 5 & 2 \\
\hline
\end{tabular}

Table 25 hasil pengamatan PJ PTM terhadap alumni diklat yaitu sebagian besar telah melakukan pencatatan dan pelaporan secara manual namun jarang atau tidak pernah melakukan pencatatan dan pelaporan Posbindu PTM dengan menggunakan system informasi manajemen. 


\section{Pembahasan}

1. Manfaat pelatihan kader Posbindu PTM bagi pengembangan kader posbindu PTM

Hasil wawancara dengan alumni diklat, kader Posbindu PTM dan PJ PTM tentang manfaat pelatihan kader PTM bahwa dengan dilakukannya pelatihan terhadap kader PTM akan meningkatkan pengetahuan, pemahaman dan wawasan kader tentang tatalaksana Posbindu sesuai dengan perkembangannya sehingga kader menjadi lebih aktif, lebih produktif dan lebih mandiri.

Kegiatan pelatihan Posbindu PTM bagi kader sangatlah bermanfaat mengingat Posbindu merupakan suatu upaya untuk pemberdayaan masyarakat dalam rangka mencegah dan menanggulangi factor resiko PTM di masyarakat. Pada pelatihan tersebut diberikan pengetahuan tentang FR PTM , dampak dan upaya dalam pencegahan dan pengendalian PTM, pengetahuan tentang Posbindu, ketrampilan dan kemampuan dalam memantau FR PTM dan diberikannya ketrampilan dalam edukasi serta tindak lanjut lainnya. Oleh karena itu dengan dilakukannya pelatihan terhadap kader sangatlah berdampak positif terhadap pengembangan diri kader sehingga kader dapat lebih baik dalam menyelenggarakan kegiatan Posbindu.

2. Implementasi Rencana Tindak Lanjut (RTL) Pelatihan Kader Posbindu PTM angkatan I

a. Pelaporan dan sosialisasi pelatihan kader Posbindu PTM angkatan I

Berdasarkan wawancara dengan alumni diklat, PJ PTM dan kader PTM bahwa semua alumni diklat telah melaporkan hasil pelatihan kepada PJ PTM, demikian pula dengan sosialisasi hasil diklat, hampir seluruh alumni diklat telah mensosialisasikan hasil pelatihan kepada kader, tim PKK desa dan karang taruna di desanya. Sebagian kecil belum melakukan sosialisasi karena masih terkendala adanya pandemic covid 19.

Penyusunan RTL dilakukan oleh peserta diklat pada setiap akhir pelatihan, karena melalui RTL penyelenggara pelatihan dapat mengetahui apa yang akan dilakukan oleh peserta latih sekembalinya dari pelatihan. Selain itu RTL dapat digunakan sebagai alat ukur dalam melakukan evaluasi pasca pelatihan.

Rencana tindak lanjut adalah suatu proses secara sistematis untuk mempersiapkan kegiatan-kegiatan dalam rangka mencapai suatu tujuan tertentu. (Kurikulum Pelatihan Bagi Tenaga PelatihTraining of Training (TOT) Pengendalian Faktor Risiko Penyakit Tidak Menular Bagi Kader Posbindu Di Wilayah Kerja, 2019). Rencana Tindak Lanjut dapat digunakan sebagai alat ukur komitmen peserta latih dalam berbuat sesuatu setelah selesai pelatihan.

Komitmen alumni diklat kader Posbindu PTM angkatan I cukup baik hal ini dibuktikan hampir seluruh alumni diklat telah melakukan sosialisasi hasil pelatihan kepada kader Posbindu PTM, Tim PKK desa dan masyarakat pada umumnya. Sehingga dengan adanya sosialisasi diharapkan kader Posbindu yang belum berkesempatan untuk mengikuti pelatihan secara langsung dapat mengetahui perkembangan terkini pengelolaan Posbindu PTM yang sesuai standart. Harapan kedepannya dengan sosialisasi para kader dapat lebih aktif, inovatif dan lebih mandiri dalam pengelolaan Posbindu PTM sehingga factor resiko penyakit tidak menular di masyarakat bisa dikendalikan.

b. Mempersiapkan dan melengkapi sarana Posbindu

Berdasarkan wawancara dengan alumni diklat, PJ PTM dan kader PTM tentang persiapan dan kelengkapan sapras Posbindu PTM di tempat alumni diklat didapatkan hampir setengah menyatakan bahwa Posbindu di tempatnya telah memiliki sarana dan prasarana yang cukup dan sesuai standart. Beberapa menyatakan masih proses penganggaran untuk melengkapi sarana prasarana Posbindu dari dana desa. Setelah dilakukan klarifikasi terhadap kader Posbindu di tempat masing-masing alumni diklat didapatkan pernyataan yang sama. Hal senada juga disampaikan oleh PJ PTM bahwa ada beberapa Posbindu yang saprasnya masih belum mencukupi. 
Untuk mencapai keberhasilan program Posbindu PTM perlu dikembangkan strategi pelaksanaan kegiatan salah satu diantaranya adalah fasilitasi ketersediaan sarana prasarana yang memadai. (Pedoman Umum Pos Pembinaan Terpadu Penyakit Tidak Menular, 2014)

Ketersediaan sarana dan prasarana yang sesuai standart sangatlah penting agar kegiatan Posbindu dapat berjalan dengan baik. Advokasi dan dukungan dari pemerintah desa, dinas kesehatan/puskesmas setempat sangatlah penting terkait dengan pemberian bantuan sarana prsarana yang diperlukan untuk operasional kegiatan Posbindu.

c. Menyusun rencana kerja

Berdasarkan wawancara dengan alumni diklat dan kader PTM tentang penyusunan rencana kerja setelah pelatihan didapatkan bahwa sebagian besar alumni diklat telah membuat rencana kerja Posbindu sedangkan hampir setengahnya baru proses penyusunan dan pengajuan rencana kerja Posbindu dikarenakan adanya pandemic covid 19 hal ini sesuai dengan pernyataan kader Posbindu PTM bahwa penyusunan rencana kerja belum selesai karena adanya pandemic Covid 19.

Pada pelatihan kader Posbindu diharapkan setelah pelatihan selesai peserta latih menyusun rencana kerja, hal ini telah dilakukan oleh sebagian besar alumni diklat namun karena pandemic covid 19 yang belum selesai menjadi kendala bagi sebagian peserta diklat untuk menyusun rencana kerja.

3. Pelaksanaan upaya pencegahan dan pengendalian FR PTM secara preventif dan promotif oleh alumni diklat kader Posbindu PTM angkatan I

Berdasarkan evaluasi pelaksanaan upaya pencegahan dan pengendalian FR PTM secara preventif dan promotif oleh alumni diklat setelah pelatihan adalah ada beberapa kegiatan yang jarang dan tidak pernah dilakukan oleh sebagian peserta diklat yaitu melakukan demo makanan sehat, melakukan kunjungan rumah untuk memberikan konseling kesehatan dan membuat leaflet tentang upaya pencegahan dan pengendalian FR PTM. Setelah dilakukan klarifikasi kepada kader Posbindu PTM dan PJ PTM didapatkan hasil yang sama.

Penyakit tidak menular dapat dicegah dengan mengendalikan factor resikonya. Mencegah dan mengendalikan factor resiko relative lebih murah bila dibandingkan dengan biaya pengobatan PTM. Salah satu upaya pengendalian factor resiko PTM adalah dengan upaya preventif dan promotif. Termasuk dalam upaya tersebut adalah menyebarluaskan secara massif sosialisasi pencegahan dan pengendalian factor resiko PTM kepada seluruh masyarakat.. (Pedoman Umum Pos Pembinaan Terpadu Penyakit Tidak Menular, 2014)

Upaya pencegahan dan pengendalian FR PTM secara preventif dan promotif oleh alumni diklat sebagian sudah dilakukan namun ada beberapa kegiatan yang belum terlaksana dengan baik antara lain pelaksanaan kunjungan rumah untuk konseling kesehatan, hal ini dikarenakan adanya pandemic covid-19, sesuai pernyataan dari alumni diklat bahwa kegiatan konseling tidak dilakukan secara kunjungan rumah namun dilaksanakan di tempat kegiatan posbindu, untuk kegiatan demo makanan sehat dan pembuatan leaflet tidak dilaksanakan dengan alasan adanya keterbatasan dana pada masing-masing Posbindu. Hal ini sesuai dengan yang disampaikan oleh kader Posbindu PTM bahwa ada beberapa kegiatan yang tidak bisa dilaksanakan karena adanya keterbatasan dana dan adanya pandemic covid 19.

Factor resiko perilaku PTM dapat dirubah dengan meningkatkan pengetahuan dan kemampuan masyarakat untuk menerapkan gaya hidup sehat melalui kegiatan promotif dan preventif, salah satunya dengan melakukan edukasi factor resiko PTM dengan tepat dan benar, Karena dengan edukasi yang benar akan membantu masyarakat menemukan masalah kesehatan yang berkaitan dengan factor resiko dan cara mengatasi sesuai kemampuan yang dimiliki. Peran tersebut dapat dilakukan oleh kader kesehatan yang telah terlatih dengan baik, hal ini telah dilaksanakan oleh kader para alumni diklat walaupun ada sebagian kecil kegiatan yang belum terlaksana karena adanya kendala pandemic covid dan keterbatasan dana yang ada. 


\section{COMMUNITY : Jurnal Pengabdian Kepada Masyarakat Vol. 1 No. 1 Mei 2021 e-ISSSN : 2797-0159 | p-ISSN : 2797-0574}

4. Pelaksanaan upaya pengendalian FR PTM dengan deteksi dini dan monitoring oleh alumni diklat kader Posbindu PTM angkatan I

Berdasarkan evaluasi pelaksanaan upaya pencegahan dan pengendalian FR PTM dengan deteksi dini dan monitoring oleh alumni diklat setelah pelatihan adalah ada kegiatan yang jarang dan tidak pernah dilakukan oleh sebagian partisipan yaitu melakukan pemeriksaan klinik payudara/sadanis, melakukan pemeriksaan tajam penglihatan dan tajam pendengaran serta melakukan tindak lanjut dini saat kegiatan Posbindu. Setelah dilakukan klarifikasi kepada kader Posbindu dan PJ PTM didapatkan hasil yang sama.

FR PTM adalah suatu kondisi yang secara potensial berbahaya dan dapat memicu terjadinya penyakit tidak menular pada seseorang atau kelompok tertentu. Jika FR PTM yang dapat diubah tidak dikendalikan maka secara alami penyakit akan berjalan menjadi fase akhir PTM. Sebelum menjadi fase akhir PTM dapat dideteksi secara dini dengan menemukan adanya factor fisiologi seperti obesitas, tekanan darah tinggi, gula darah tinggi, benjolan payudara dan lain.lain. (Kurikulum Pelatihan Bagi Tenaga PelatihTraining of Training (TOT) Pengendalian Faktor Risiko Penyakit Tidak Menular Bagi Kader Posbindu Di Wilayah Kerja, 2019).

Dalam pengendalian FR PTM seorang kader posbindu melakukan wawancara FR PTM, pemeriksaan FR PTM dan pengukuran FR PTM. Pada pemeriksaan FR PTM dibutuhkan cara pemeriksaan yang benar untuk mendapatkan informasi factor resiko PTM yang dimilikinya. Dengan pemeriksaan FR PTM yang benar masyarakat akan terbantu untuk ke fase lebih lanjut dan apabila ditemukan factor resiko yang mengarah pada PTM disarankan agar masyarakat melakukan konfirmasi lanjutan berupa pemeriksaan dan penanganan di fasilitas kesehatan. Seorang kader Posbindu PTM dapat melakukan pemeriksaan tersebut hal ini telah dilakukan oleh alumni diklat namun belum semua pemeriksaan dapat dilakukan seperti pemeriksaan sadanis, pemeriksaan tajam penglihatan, pemeriksaan tajam pendengaran dan tindak lanjut dini.

Pemeriksaan Sadari/Sadanis adalah upaya deteksi dini kanker payudara untuk mengeidentifikasi secara dini adanya kanker payudara sehingga diharapkan dapat diterapi dengan teknik yang dampak fisiknya kecil dan punya peluang lebih besar untuk sembuh. (Modul Pelatihan Bagi Pelatih Pelayanan Terpadu Penyakit Tidak Menular (Pandu PTM) di Fasilitas Kesehatan Tingkat Pertama (FKTP), 2018). Deteksi dini kanker payudara juga dapat dilakukan terintegrasi dengan skrining kanker leher Rahim, hal ini sesuai dengan pernyataan beberapa alumni diklat bahwa sadanis tidak dilakukan di Posbindu dikarenakan kondisi tempat yang tidak memungkinkan untuk pemeriksaan sadanis karena kegiatan Posbindu dilakukan diruangan terbuka, kendala lainnya belum ada yang melaksanakan, masyarakat tidak bersedia dilakukan pemeriksaan karena malu selain itu ada sebagian informan menyatakan bahwa kegiatan sadanis sudah terintegrasi dengan pemeriksaan IVA dan pap smear. Untuk kegiatan pemeriksaan tajam pendengaran dan penglihatan baru proses akan disosialisasikan karena sebelumnya belum pernah dilakukan dengan alasan keterbatasan alat yang tersedia.

5. Pelaksanaan rujukan pada warga dengan resiko penyakit tidak menular oleh alumni diklat kader Posbindu angkatan I

Berdasarkan evaluasi pelaksanaan upaya pencegahan dan pengendalian factor resiko penyakit tidak menular dengan melakukan rujukan pada warga yang beresiko penyakit tidak menular oleh alumni diklat didapat hasil bahwa sebagian alumni diklat sudah melakukan rujukan saat kegiatan Posbindu dan sebagian jarang dan belum pernah melakukan rujukan pada warga dengan resiko PTM. Hal ini sesuai dengan hasil pengamatan kader Posbindu PTM dan PJ PTM.

Kegiatan identifikasi factor resiko PTM dan rujukan merupakan tahapan layanan terakhir setelah ada hasil dari wawancara, pengukuran dan pemeriksaa. Penilaian factor resiko PTM dilakukan pada setiap individu untuk masing-masing factor resiko. (Kurikulum Pelatihan Bagi Tenaga PelatihTraining of Training (TOT) Pengendalian Faktor Risiko Penyakit Tidak Menular Bagi Kader Posbindu Di Wilayah Kerja, 2019). Rujukan dilakukan jika individu memiliki factor resiko PTM dengan ditunjang hasil pemeriksaan dan pengukuran dengan nilai yang tidak 
normal. Kader Posbindu dapat melakukan rujukan ke Puskesmas dan berkonsultasi dengan tenaga kesehatan. Hal ini telah dilakukan oleh hampir setengah alumni diklat, ada sebagian yang jarang melakukan dengan alasan belum ada kasus yang perlu dirujuk.

6. Pelaksanaan pencatatan dan pelaporan factor resiko penyakit tidak menular oleh alumni diklat kader Posbindu PTM angkatan I

Berdasarkan evaluasi dan pengamatan oleh kader Posbindu PTM didapatkan hasil bahwa sebagian besar alumni diklat telah melakukan kegiatan pencatatan dan pelaporan FR PTM dan sebagian kecil belum pernah melakukan. Hasil pengamatan PJ PTM bahwa sebagian besar telah melakukan kegiatan pencatatan dan pelaporan Posbindu secara manual namun untuk pencatatan dan pelaporan Posbindu PTM dengan menggunakan SIM setengah dari responden jarang melakukan dan sebagian kecil tidak pernah melakukan.

Tingginya permasalahan PTM di Indonesia memerlukan upaya pengendalian melalui promosi, deteksi dini, pengobatan dan rehabilitasi. Upaya tersebut didukung oleh penyediaan data dan informasi yang tepat dan akurat. Oleh karena itu perlu dibuat suatu sistem surveilans tentang factor resiko PTM, (Kurikulum Pelatihan Bagi Tenaga PelatihTraining of Training (TOT) Pengendalian Faktor Risiko Penyakit Tidak Menular Bagi Kader Posbindu Di Wilayah Kerja, 2019)

Pencatatan dan pelaporan hasil kegiatan Posbindu PTM dilakukan secara manual dan/atau menggunakan SIM oleh petugas pelaksana Posbindu PTM maupun oleh petugas Puskesmas. Petugas Puskesmas mengambil data hasil pencatatan posbindu PTM atau menerima hasil pencatatan dari petugas pelaksana posbindu PTM. Hasil pencatatan ini dianalisa untuk digunakan dalam pembinaan, sekaligus melaporkan ke instansi terkait secara berjenjang. Hasil pencatatan dan pelaporan kegiatan posbindu PTM merupakan sumber data yang penting untuk pemantauan dan penilaian perkembangan kegiatan Posbindu PTM. Pencatatan dan pelaporan di masing-masing posbindu alumni diklat sudah dilaksanakan hanya mekanisme pelaksanaan antara posbindu satu dengan yang lain berbeda. Hal ini sesuai dengan pernyataan dari PJ PTM bahwa semua Posbindu di tempat alumni diklat hampir semuanya sudah melakukan namun secara manual, untuk pelaporan dengan system informasi setengah dari kader Posbindu jarang melakukan dikarenakan kendala pada pemakaian perangkat laptop dan jaringan.

7. Dukungan terhadap implementasi hasil diklat kader Posbindu PTM

Berdasarkan wawancara dengan alumni diklat, kader PTM dan PJ PTM tentang dukungan implementasi hasil pelatihan yaitu alumni diklat menyatakan bahwa kepala desa, Toga/Tomas, tim PKK serta dinas kesehatan dan Puskesmas sangat mendukung pelaksanaan kegiatan Posbindu sebagai aplikasi dari hasil pelatihan. Hal yang sama disampaikan oleh kader Posbindu PTM. Demikian pula oleh PJ PTM bahwa dinas kesehatan sangat mendukung kegiatan Posbindu dengan pemberian Posbindu kit, pelatihan/sosialisasi kader serta pendampingan kader Posbindu PTM.

PTM dapat dicegah melalui pengendalian factor resiko dengan peningkatan kesadaran, dan kepedulian masyarakat terhadap FR PTM. Dengan demikian diharapkan kasus PTM dapat dicegah. Dalam pelaksanaannya agar tercapai keberhasilan program yang diharapkan diperlukan dukungan dan advokasi dari pemerintah, pihak legislative, pemerintah daerah serta pemangku kepentingan. Diperlukan juga peran pemerintah dan masyarakat dalam perencanaan, pelaksanaan, monitoring dan evaluasi kegiatan tersebut. Dari hasil penelitian ini dukungan pemerintah desa, tokoh agama dan masyarakat secara umum di wilayah kegiatan posbindu dari alumni diklat cukup baik dalam mendukung keberlangsungan kegiatan Posbindu baik dukungan material dan dukungan moril kepada kader PTM.

8. Hambatan terhadap implementasi hasil diklat kader Posbindu PTM

Berdasarkan wawancara dengan alumni diklat, kader PTM dan PJ PTM tentang hambatan dalam mengimplementasikan hasil diklat yaitu beberapa alumni diklat menyatakan bahwa 


\section{COMMUNITY : Jurnal Pengabdian Kepada Masyarakat \\ Vol. 1 No. 1 Mei 2021 e-ISSSN : 2797-0159 | p-ISSN : 2797-0574}

hambatan dalam implementasi hasil diklat dalam penyelenggaraan Posbindu yang sesuai standard adalah masih kurangnya alat kesehatan yang sesuai standart, alumni diklat merasa kesulitan untuk menyakinkan masyarakat agar paham tentang pentingnya deteksi dini PTM serta kondisi pandemic yang saat ini tengah berlangsung sangat menghambat dalam mengimplementasikan hasil diklat. Hal yang sama disampaikan oleh kader Posbindu PTM. Sedangkan PJ PTM menyatakan hambatan terbesar untuk implementasi hasil diklat karena adanya pandemic corona sehingga minat masyarakat untuk datang ke Posbindu sedikit berkurang.

Dalam pelaksanaannya Posbindu PTM selalu dilakukan pemantauan dan penilaian oleh petugas Puskesmas, salah satu tujuannya untuk mengidentifikasi masalah dan hambatan yang dihadapi oleh posbindu PTM serta menentukan alternative pemecahan masalahnya.

\section{KESIMPULAN}

Pelatihan kader Posbindu PTM angkatan I tahun 2020 yang diselenggarakan di Latkesmas Murnajati cukup efektif dan bermanfaat karena pada pelatihan tersebut peserta diberikan pengetahuan baik secara teori maupun praktik tentang upaya penanggulangan FR PTM dan pengelolaan Posbindu PTM secara benar.

Sebagian besar alumni diklat telah melaksanakan Rencana Tindak Lanjut dari pelatihan yaitu pelaporan, sosialisasi hasil diklat dan penyusunan rencana kerja Posbindun PTM, sebagian besar peserta diklat telah melaksanakan upaya pencegahan dan pengendalian faktor resiko PTM secara preventinf dan promotif, sebagian besar peserta diklat telah melaksanakan upaya pengendalian penyakit tidak menular dengan deteksi dini dan monitoring, setengah paserta diklat telah melaksanakan rujukan pada warga dengan resiko penyakit tidak menular, sebagian besar peserta diklat telah melakukan kegiatan pencatatan dan pelaporan factor resiko PTM secara manual namun untuk pelaporan system informasi setengah dari peserta diklat jarang melakukan.

Kepala desa, Toga/Tomas, tim PKK desa, Dinas kesehatan dan Puskesmas sangat mendukung pelaksanaan kegiatan Posbindu PTM ditempat peserta diklat sebagai aplikasi dari hasil pelatihan.

Hambatan dalam implementasi hasil diklat dalam penyelenggaraan Posbindu PTM yang sesuai standard adalah sarana prasarana yang belum sesuai standart, kurangnya kesadaran masyarakat tentang pentingnya deteksi dini PTM serta kondisi pandemic yang saat ini tengah berlangsung sangat menghambat dalam mengimplementasikan hasil diklat.

\section{DAFTAR PUSTAKA}

Arikunto, S. (2002). Prosedur Penelitian Suatu Pendekatan Praktik. Jakarta: PT Rineka Cipta. Herdianti, Y. H. (2019). Evaluasi Pasca Pelatihan Perilaku Caring Pada Perawat di Unit Rawat Inap RSUD Pasar Rebo. Skripsi Fakultas Kesehatan Masyarakat Universitas Indonesia. Husaini, U., \& Purnomo, S. (2009). Metodologi Penelitian Sosial. Jakarta: PT Bumi Aksara.

Izhar, M. D. (2019). Pelatihan Kader Posbindu PTM : Hipertensi. Jambi: FKM Universitas Jambi.

Kurikulum Pelatihan Bagi Tenaga PelatihTraining of Training (TOT) Pengendalian Faktor Risiko Penyakit Tidak Menular Bagi Kader Posbindu Di Wilayah Kerja. (2019). Jakarta: Kementerian Kesehatan RI Direktorat Pencegahan dan Pengendalian Penyakit Tidak Menular Direktorat Pencegahan dan Pengendalian Penyakit.

Kirkpatrick, D. L., \& Kirkpatrick, J. D. (2007). Implementing The Four Levels. California: Berett Koehler Publisher.

Modul Pelatihan Bagi Pelatih Pelayanan Terpadu Penyakit Tidak Menular (Pandu PTM) di Fasilitas Kesehatan Tingkat Pertama (FKTP). (2018). Jakarta: Direktorat Jendral Pencegahan dan Pengendalian Penyakit, Direktorat Pencegahan dan Pengendalian Penyakit Tidak Menular Kemenkes RI.

Maleong, L. J. (2004). Metodologi Penelitian Kualitatif. Bandung: PT. Remaja Rosdakarya. 
Nursalam. (2016). Metodologi Penelitian Ilmu Keperawatan. Jakarta: Salemba Medika.

primiyani, Y., Masruf, \& Hardisman. (2019). Analisis Pelaksanaan Program Pos Pembinaan Terpadu Penyakit Tidak Menular di kota Solok. Jurnal Kesehatan Andalas.

Pedoman Umum Pos Pembinaan Terpadu Penyakit Tidak Menular. (2014). Jakarta: Kementerian kesehatan RI Ditjen Pengendalian Penyakit dan Penyehatan Lingkungan Direktorat Pengendalian Penyakit Tidak Menular.

Ramadhan, S. (2016). Penerapan Model Empat Level Kirkpatrick Dalam Evaluasi Program Pendidikan Dan Pelatihan Aparatur Di Pusdiklat Migas. ejurnal ppsdmmigas.esdm.go.id.

Ratna, S. (2016). Evaluasi Program Pasca Diklat. Jakarta: Lembaga Administrasi Negara.

Ritonga, R., Saepudin, A., \& Wahyudin, u. (2019). Penerapan Model Evaluasi Kirkpatrick Empat Level Dalam Mengevaluasi Program Diklat Di Balai Besar Pelatihan Pertanian (BBPT) Lembang. Jurnal Pendidikan NOn formal Vol. 14 No 1 FKM UI.

Sudarto. (1997). Metodologi Penelitian Filsafat. Jakarta: Raja Grafindo Persada.

Sugiyono. (2007). Metode Penelitian KUantitatif,Kualitatif dan $R \&$ D. Bandung: CV Alfabeta. Widoyoko, E. P. (2009). Evaluasi Program Pelatihan. Yogjakarta Pustaka Pelajar. 